\title{
Atopic phenotype associations with rs7927894 inter gene polymorphism on chromosome 11q13.5 in Czech adult patients with atopic dermatitis
}

\author{
Vašků V', Kozáčiková $Z^{1}$, Bienertová-Vašků J², Petrucha $V^{2}$, Trhanová $K^{2}$ and Vašků $A^{2}$ \\ ${ }^{1} 1^{\text {st }}$ Department of Dermatology, St. Ann's Faculty Hospital, Faculty of Medicine, Masaryk University Brno, Czech Republic \\ ${ }^{2}$ Department of Pathophysiology, Faculty of Medicine, Masaryk University Brno, Czech Republic
}

\begin{abstract}
Aim: Aim of the study was phenotype-genotype association analysis of rs7927891 polymorphism in adult patients with Atopic Dermatitis (AD).

Material and methods: Finally, 90 patients were enrolled to the study, 31 men ( $30 \pm 10$ years) and 59 women ( $31 \pm 11$ years). Among them, $65 \%$ of men and $75 \%$ of women reported positive family history of atopic phenotype.

Results: We did not observe significant differences in genotype distribution and/or allelic frequencies between AD men and women in polymorphism rs792894. But, the CT genotype of polymorphism rs7927894 on chromosome 11q13.5 was more than 4times more frequently observed in AD women with elevated levels of the total $\mathrm{IgE}$ above $158 \mathrm{IU} / \mathrm{ml}$. In AD men, a significant association of polymorphism rs7927894 on chromosome 11q13.5 with atopic phenotype/predisposition was found: the genotypes $\mathrm{CC}$ and TT are 6 times more frequent in AD men with other atopic phenotype (asthma, atopic rhinitis) compared to AD men without it. The TT genotype of the polymorphism was 4 times more frequent in men with positive family history of atopic phenotypes.

Conclusion: We identified significant risky genotypes for some AD phenotypes in rs7927894 polymorphism in patients with AD, differently for adult AD men and women.
\end{abstract}

\section{Introduction}

Atopic Dermatitis (AD), or eczema, is one of the most common chronic inflammatory skin diseases with prevalence rates of up to $20 \%$ in children and $3 \%$ in adults. It commonly starts during infancy and frequently precedes or co-occurs with asthma and rhinitis. It is characterized by dry skin, intense pruritus, and a typical age-related distribution of inflammatory lesions with frequent bacterial and viral superinfections. Profound alterations in skin barrier function and immunologic abnormalities are considered key components affecting the development and severity of $\mathrm{AD}$, but the exact cellular and molecular mechanisms remain incompletely understood [1].

Atopic dermatitis (AD) has high heritability. Apart from filaggrin ( $F L G)$, the genes influencing AD are largely unknown. An association signal was recently identified at 11q13.5 (rs7927894), downstream of C11orf3 [2-4]. The polymorphism rs7927894 is located in an intergenic region $38 \mathrm{~kb}$ downstream of C11orf30 (chromosome 11 open reading frame 30) and $68 \mathrm{~kb}$ upstream of LRRC32 (leucine rich repeat containing 32). C11orf30 and $L R R C 32$ are found to be ubiquitously expressed, including in tissues relevant to atopic dermatitis such as skin and peripheral blood mononuclear cells. The potential involvement of C11orf30 in multiple inflammatory and malignant epithelial diseases (atopic dermatitis, Crohn's disease and adenocarcinoma) strongly suggests a role for C11orf30 in epithelial immunity, growth and/or differentiation [3] Approximately 13\% of individuals of European origin are homozygous for rs7927894 [T], and their risk of developing atopic dermatitis was calculated to be 1.47 times higher that of noncarriers [5].
In this study we performed genotype-phenotype study for rs7927894 single nucleotide polymorphism on chromosome 11q13.5 in a group of 90 adults with atopic dermatitis.

\section{Material and methods}

\section{Patients}

Total of 90 patients with $\mathrm{AD}$, diagnosed and treated at the $1^{\text {st }}$ Department of Dermatology of St Ann's Faculty Hospital Brno were recruited to the study. The patients were diagnosed according to the generally accepted criteria Hanifin and Rajka [6].

Demographic data are presented in Table 1 and 2. None phenotypic differences between man and women $(\mathrm{M} / \mathrm{W})$ were significant.

All these patients were genotyped for rs7927894 by conventional PCR method with restriction analysis.

This study was approved by the Committee for Ethics of Medical Experiments on Human Subjects, Faculty of Medicine, Masaryk

Correspondence to: Prof. Anna Vašků, Head of the Department of Pathological Physiology, Vice-Dean for External Relation, Faculty of Medicine, Masaryk University, University Campus Bohunice, Kamenice 5, 62500 Brno-Bohunice, Czech Republic, Fax: +420 054949 4340, Tel: +420549498262; E-mail: avasku@med.muni.cz

Key words: atopic dermatitis, gene polymorphism, genotype-phenotype study, rs7927891

Received: April 10, 2015; Accepted: May 20, 2015; Published: May 24, 2015 
Table 1. Descriptive characteristics- personal history.

\begin{tabular}{|l|c|}
\hline Sex M/ W (N=90) & $32 \% / 68 \%$ \\
\hline Age M/ W (years) & $30 \pm 10 / 31 \pm 11$ \\
\hline Personal history of atopic phenotype (s) M/W & $65 \% / 47 \%$ \\
\hline Personal history of aero allergy M/W & $90 \% / 73 \%$ \\
\hline Personal history of food allergy & $29 \% / 41 \%$ \\
\hline Personal history of other complex disease (not atopy) M/W & $23 \% / 39 \%$ \\
\hline Personal history of diabetes mellitus & $0 \% / 5 \%$ \\
\hline Personal history of cardiovascular diseases & $11 \% / 18 \%$ \\
\hline Personal history of GIT diseases M/W & $8 \% / 12 \%$ \\
\hline Personal history of thyreopathy & $0 \% / 7 \%$ \\
\hline
\end{tabular}

$\mathrm{M} / \mathrm{W}-\mathrm{men} /$ women

Table 2. Descriptive characteristics-family history

\begin{tabular}{|l|c|}
\hline Family history of atopy M/W & $65 \% / 75 \%$ \\
\hline Family history of other than atopic diseases $\mathrm{M} / \mathrm{W}$ & $71 \% / 80 \%$ \\
\hline Family history of psoriasis M/W & $3 \% / 19 \%$ \\
\hline Family history of thyreopathy M/W & $10 \% / 45 \%$ \\
\hline Family history of diabetes mellitus M/W & $53 / 59 \%$ \\
\hline Family history of cancer M/W & $36 \% / 60 \%$ \\
\hline Family history of cardiovascular disease M/W & $36 \% / 66 \%$ \\
\hline
\end{tabular}

M/W-men/women

University, Brno (no. 64/93, 1993) and was performed in adherence to the Declaration of Helsinki Guidelines. Participants gave their written informed consent which has been archived.

\section{Genotyping}

Genotyping was performed using PCR and restriction analysis.

Genomic DNA was purified from peripheral blood leukocytes by the standard method using the phenol-chloroform extraction and the proteinase $\mathrm{K}$ digestion of cells.

Genotype in rs7927894 polymorphism on chromosome 11q13.5 was detected using PCR reaction (primers $5^{\prime}$ - TGT TAA GAA TCC CCA CCT CAC T- $3^{\prime}$ and $5^{\prime}$-GCC TCA GTT TCC TCA TGG TAA G-3') with HINFI restriction analysis. The genotypes were distinguished as CT $(9,85,106,182$ / 9, 85, 288 bp), CC $(9,85,106,182 / 9,85,106,182$ bp $)$ and TT $(9,85,288 / 9,85,288 \mathrm{bp})$.

The genotypes were determined by $2 \%$ agarose Serva electrophoresis.

\section{Statistics}

Statistical analysis was performed using STATISTICA software (StatSoft, version 11). One-tailed Fisher exact test was used for all categorical data, Mann-Whitney U-test and Kruskall-Wallis test for continuous data. Four different modes of inheritance were tried: allele-based additive model (one allele vs. the other), genotypebased dominant (more common homozygote vs. rarer allele carrier), codominant/recessive (rarer homozygote vs. common allele carrier) and overdominant model (both homozygotes vs. heterozygote).

\section{Results}

We did not observe significant differences in genotype distribution and/or allelic frequencies in the detected polymorphism between men and women (data not presented).

No significant genotype/phenotype association was found when $\mathrm{AD}$ men and women have been evaluated all together.
After division of the group of patients to men and women, some differences have been observed: in $\mathrm{AD}$ women, the CT genotype of polymorphism rs7927894 on chromosome 11q13.5 was more frequently detected in $\mathrm{AD}$ women with elevated levels of $\operatorname{IgE}(\mathrm{OR}=4.76$, 95\% CI 1.19-18.98, $\mathrm{P}=0.02$, Table 3). In $\mathrm{AD}$ women, we found a significant association of polymorphism rs7927894 on chromosome $11 \mathrm{q} 13.5$ with atopic phenotype: the genotypes CC and TT are 6 times more frequent in $\mathrm{AD}$ men with other atopic phenotype compared to $\mathrm{AD}$ men without it $(\mathrm{OR}=6.22,95 \% \mathrm{CI} 1.212-31.938, \mathrm{P}=0.03)$. At the same time, the TT genotype was $4 \mathrm{x}$ more frequent in $\mathrm{AD}$ men with positive family history of atopic phenotypes $(\mathrm{OR}=4.286,95 \% \mathrm{CI} 0.444$ 41.364, $\mathrm{P}=0.05$, Table 4).

\section{Discussion}

In addition to $F L G$, two European GWAS on atopic dermatitis established four susceptibility loci (C11orf30, OVOL1, ACTL9, and RAD50/IL13/KIF3A) [2-3]. Single nucleotide polymorphism rs7927894 appears to mark a genuine eczema susceptibility locus [7]. Recently, polymorphism C11orf30-rs2155219 was found to double the risk of poly-sensitization (specific IgE/4 allergens) [8].

According to our study, the TT genotype in rs7927894 of was 4 times more frequent in $\mathrm{AD}$ patients with positive family history of atopic phenotypes, but only in men. Austrian study refers a significant association of the rs7927894 variant on chromosome 11q13.5 with atopic dermatitis. But, genotype-phenotype study analysis revealed no significant association of rs7927894 with early age of onset of the disease, concomitant asthma and allergic rhinoconjunctivitis, total serum IgE levels and family history of atopy [9] which is not in agreement with our results. Different results could be caused by strictly separated statistical analysis of $\mathrm{AD}$ men and women data performed in our study.

Other polymorphic sites have been discovered in other QWAS studies [10-11], probably many of them in linkage disequilibrium and with some inter population differences.

We identified significant risky genotypes for some $\mathrm{AD}$ phenotypes in rs7927894 polymorphism in patients with $\mathrm{AD}$, differently for adult $\mathrm{AD}$ men and women.

\section{Acknowledgement}

This publication was written at Masaryk university as part of the project "Experimentální molekulární patofyziologie vybraných

Table 3. rs7927894 (11q13.5) genotype and IgE levels in AD women.

\begin{tabular}{|c|c|c|c|}
\hline rs7927894 (11q13.5) & $\begin{array}{c}\text { No elevated IgE } \\
(<\mathbf{1 5 8} \text { IU/ml) }\end{array}$ & $\begin{array}{c}\text { Elevated IgE } \\
(\mathbf{v} \geq \mathbf{v 1 5 8} \mathbf{~ I U / m l})\end{array}$ & $\begin{array}{c}\text { Row } \\
\text { Totals }\end{array}$ \\
\hline CC & $11(61 \%)$ & $17(41 \%)$ & 28 \\
\hline CT & $3(17 \%)$ & $20(49 \%)$ & 23 \\
\hline TT & $4(22 \%)$ & $4(10 \%)$ & 8 \\
\hline All Grps & 18 & 41 & 59 \\
\hline
\end{tabular}

Table 4. rs7927894 (11q13.5) genotype and family history of atopy in AD men.

\begin{tabular}{|c|c|c|c|}
\hline rs7927894 (11q13.5) & $\begin{array}{c}\text { Family history of } \\
\text { atopy }\end{array}$ & $\begin{array}{c}\text { No family history } \\
\text { of atopy }\end{array}$ & $\begin{array}{c}\text { Row } \\
\text { Totals }\end{array}$ \\
\hline CC & $7(35 \%)$ & $4(36 \%)$ & 11 \\
\hline CT & $7(35 \%)$ & $7(64 \%)$ & 14 \\
\hline TT & $6(30 \%)$ & $0(0 \%)$ & 6 \\
\hline All Grps & 20 & 11 & 31 \\
\hline
\end{tabular}


komplexních chorob/ stavů”, MUNI/A/1549/2014 and of the project "Faktory ovlivňující průběh a léčbu u chronických a závažných kožních diagnóz", MUNI/A/1557/2014 with the support of the Specific University Research Grant, as provided by the Ministry of Education, Youth and Sports of the Czech Republic in 2015.

\section{References}

1. Bieber T (2008) Atopic dermatitis. N Engl J Med 358: 1483-1494. [Crossref]

2. Rodríguez E Baurecht H, Herberich E, Wagenpfeil S, Brown SJ, et al. (2009) Metaanalysis of filaggrin polymorphisms in eczema and asthma: robust risk factors in atopic disease. J Allergy Clin Immunol 123: 1361-1370. [Crossref]

3. Esparza-Gordillo J Weidinger S, Fölster-Holst R, Bauerfeind A, Ruschendorf F, et al. (2009) A common variant on chromosome 11q13 is associated with atopic dermatitis. Nat Genet 41: 596-601. [Crossref]

4. Paternoster L, Standl M, Chen CM, Ramasamy A, Bønnelykke K, et al. (2011) Metaanalysis of genome-wide association studies identifies three new risk loci for atopic dermatitis. Nat Genet 44: 187-192. [Crossref]
5. Esparza-Gordillo J Marenholz I, Lee YA (2010) Genome-wide approaches to the etiology of eczema. Curr Opin Allergy Clin Immunol 10: 418-426. [Crossref]

6. Hanifin JM, Rajka G (1980) Diagnostic features of atopic dermatitis. Acta Derm Venereol Suppl 92: 44-47. [Crossref]

7. O'Regan GM Campbell LE, Cordell HJ, Irvine AD, McLean WH, et al. (2010) Chromosome 11q13.5 variant associated with childhood eczema: an effect supplementary to filaggrin mutations. J Allergy Clin Immunol 125: 170-174. [Crossref]

8. Amaral AF Minelli C, Guerra S, Wjst M, Probst-Hensch N, et al. (2015) The locus C11 1orf30 increases susceptibility to poly-sensitization. Allergy 70: 328-333. [Crossref]

9. Greisenegger EK Zimprich F, Zimprich A, Gleiss A, Kopp T (2013) Association of the chromosome 11q13.5 variant with atopic dermatitis in Austrian patients. Eur J Dermatol 23: 142-145. [Crossref]

10. Sun LD Xiao FL, Li Y, Zhou WM, Tang HY, et al. (2011) Genome-wide association study identifies two new susceptibility loci for atopic dermatitis in the Chinese Han population. Nat Genet 43: 690-694. [Crossref]

11. Ellinghaus D Baurecht H, Esparza-Gordillo J, Rodríguez E, Matanovic A, et al. (2013) High-density genotyping study identifies four new susceptibility loci for atopic dermatitis. Nat Genet 45: 808-812. [Crossref]

Copyright: @2015 Vašků V. This is an open-access article distributed under the terms of the Creative Commons Attribution License, which permits unrestricted use, distribution, and reproduction in any medium, provided the original author and source are credited. 